\title{
Allar dyr inn í velferðarpjónustuna ættu að vera pær réttu fyrir vímuefnafíkilinn
}

\section{Pórarinn \\ Tyrfingsson \\ yfirlæknir á \\ Sjúkrahúsi SÁÁ, \\ Vogi}

thorarinn@saa.is

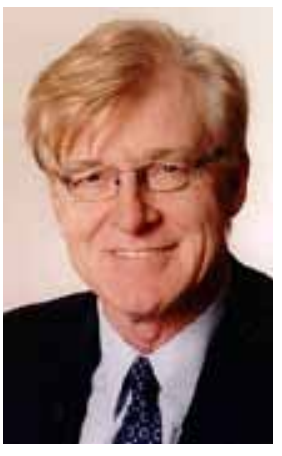

Nýlega gerðu Háskóli Íslands, Íslensk erfðagreining og Samtök áhugafólks um áfengis- og vímuefnavandann (SÁÁ) með sér samstarfssamning um kennslu og rannsóknir. Meginmarkmið samningsins er að efla gæði meðferðar við fíknisjúkdómum og pekkingu á peim. คó að samstarf pessara aðila á sviði rannsókna og meðferðar hafi verið talsvert undanfarin ár og skilað góðum árangri markar pessi samningur nokkur tímamót. Við hjá SÁÁ bindum pví vonir við að pessi samningur sé enn eitt skrefið til að auðvelda okkur að auka pekkingu á fíknisjúkdómum hér á landi.

SÁÁ er stofnað í október 1977 og hefur tekist að byggja upp og starfrækja sjálfstæðar meðferðarstofnanir og viðamikla alhliða meðferð fyrir áfengis- og vímuefnasjúklinga. Í dag reka samtökin Sjúkrahúsið Vog, tvö endurhæfingarheimili, Vík á Kjalarnesi og Staðarfell í Dölum, auk göngudeilda í Reykjavík og á Akureyri. Pessar sjúkrastofnanir vinna saman sem ein heild og veita fíklunum alhliða pjónustu. Við uppbyggingarstarfið hafa samtökin notið óvenju mikils stuðnings almennings, stjórnmálamanna, embættismanna og heilbrigðisstarfsfólks.

Heilbrigðisstarfsmenn SÁÁ líta á pennan samning sem viðurkenningu á árangursríku meðferðarstarfi á vegum sam- takanna um áratuga skeið og góðu sjúklingabókhaldi með vandaðri skráningu á neysluvanda hvers og eins. Um leið sjá peir aukin tækifæri til samskipta við aðra heilbrigðisstarfsmenn og sóknarfæri til að koma enn frekar að kennslu heilbrigðis- og velferðarstétta.

Á sjúkrahúsinu Vogi gefst einstakt tækifæri fyrir nema í heilbrigðisfræðum til að fylgjast með afeitrun fíkla og kynnast hvernig staðið er að greiningu geðrænna og líkamlegra fylgikvilla hjá peim. Sjá síðan hvernig meðferðin par stuðlar að samstarfsvilja sjúklinga og eykur peim áhugahvöt til góðra breytinga og áframhaldandi meðferðar og eftirfylgni. Í lok árs 2012 höfðu 8,8\% Íslendinga á aldrinum 15-64 ára leitað sér meðferðar á Vogi, 12,3\% karla og 5,4\% kvenna. Á hverju ári innritast par um 2200 sjúklingar af báðum kynjum á aldrinum 14-80 ára með mismunandi fíknivanda og neysluvenjur. Á Vogi hefur verið safnað skipulega miklum upplýsingum síoustu tvo áratugi um pennan stóra sjúklingahóp. Pau gögn eru afar verðmæt heimild um próun, eðli og umfang vímuefnavandans á Íslandi á peim tíma.

Stóru dyrnar á Sjúkrahúsinu Vogi eru ekki einu dyrnar sem áfengis- og vímuefnafíklar ganga um á leið sinni inn í heilbrigðispjónustuna. Sífellt fleiri vímuefnasjúklingar koma mikið veikir af fylgikvillum eða vegna eitrana á bráðamóttöku og leggjast paðan inn á geðdeild, taugadeild, smitsjúkdómadeild og meltingardeild Landspítala og lyflækningadeild Fjórðungssjúkrahússins á Akureyri. Til að auka gæði og skilvirkni pjónustunnar sem pessir sjúklingar fá purfa hinar ýmsu deildir sjúkrahúsanna og SÁÁ að auka samvinnu og samstarf enn frekar umfram pað sem nú tíðkast. Grunnurinn að slíkri sampættingu og samvinnu er aukin samvinna um kennslu og viðurkenning á nauðsyn pess að allar heilbrigðisstéttir fái góða klíníska kennslu í fíknilækningum og að tíminn í starfspjálfun par verði metinn eins og hver annar námstími bæði í grunnog framhaldsnámi.

Full pörf er á að samráðsnefndin sem sér um framkvæmd samstarfssamningsins setji sér háleit markmið. Hafa verður að leiðarljósi að gera allar dyr heilbrigðiskerfisins, og reyndar velferðarkerfisins alls, að réttum dyrum fyrir vímuefnafíkilinn. Kalla heilsugæsluna einnig til aukinnar samvinnu um kennslu í forvörnum og styðja hana til betri eftirfylgni með vímuefnafíklum.

Markmið okkar hlýtur að vera að leitast við að tryggja að hvar sem vímuefnafíkillinn parf pjónustu í velferðarkerfinu mæti hann skilningi fremur en fordómum. Forsenda pess er að næg pekking sé til staðar hjá starfsfólki pjónustunnar, pekking og skilningur sem stuðli að réttri greiningu og áhugahvöt hjá fíklinum til að sækja sér nauðsynlega meðferð og eftirfylgd. Litið verði svo á að hann pjáist af sérstökum langvinnum heilasjúkdómi sem kallar á sérhæfða faglega meðferð sem skilar oft góðum árangri ef rétt er að farið pótt hrösun sé algeng á peirri vegferð. Að meðferð lokinni parfnast sjúklingur svipaðrar eftirfylgni og aðrir sjúklingar sem pjást af langvinnum sjúkdómum og komi í árlegt eftirlit par sem greind verður áhætta á föllum og staða fylgikvilla.

All doors into the healthcare system should be the right doors for the alcohol- and drug addict

Pórarinn Tyrfingsson Medical director of Addiction Hospital Vogur 